\title{
PENINGKATAN HASIL BELAJAR MATEMATIKA MATERI PECAHAN MELALUI MODEL THE POWER OF TWO PADA SISWA KELAS III SDN PRAGAAN LAOK I KECAMATAN PRAGAAN KABUPATEN SUMENEP
}

\author{
M. Rifa i \\ Guru SDN Pragaan Laok I Pragaan Sumenep
}

\begin{abstract}
ABSTRAK
Adapun tujuan dalam penelitian tindakan kelas ini adalah untuk mendiskripsikan proses pelaksanaan pembelajaran dan peningkatan hasil belajar matematika materi pecahan melalui pembelajaran kooperatif tipe The Power Of Two pada siswa kelas III SD Negeri Pragaan Laok I semester II tahun pelajaran 2013/2014 setelah melalui pembelajaran kooperatif tipe The Power Of Two.

Prosedur peneilitian yang digunakan yaitu prosedur jenis penelitian tindakan kelas yang dilaksanakan dalam 2 siklus, setiap siklus terdiri dari 4 tahapan, yatu perencanaan, pelaksanaan, pengamatan dan refleksi. Analisis data kualitatif model pembelajaran dianalisis menggunakan analisis deskritif kualitatif dengan membandingkan siklus I dan siklus ke II sedangkan data yang berupa angka (kuantitatif) dari hasil belajar siswa dianalisis menggunakan deskriptif komparatif yaitu membandingkan nilai tes kondisi awal, nilai siklus 1 dan nilai tes siklus II kemudian direfleksi.

Hasil penelitian melalui pembelajaran kooperatif tipe The Power Of two pada siswa kelas III SD Negeri Pragaan Laok I semester II tahun pelajaran 2013/2014. Terdapat peningkatkan hasil belajar matematika materi dari siklus I ke siklus II yaitu, Nilai tuntas dari 11 siswa (55\%) menjadi 20 siswa (100\%) yaitu meningkat 9 siswa (45\%). Nilai rata-rata 61,35 meningkat menjadi 82,36 yaitu meningkat 21,01.
\end{abstract}

Kata Kunci: hasil belajar, bilangan pecahan, model the power of two

\section{PENDAHULUAN}

\section{Latar Belakang}

Matematika adalah suatu alat untuk mengembangkan cara berfikir, sehingga matematika sangat dibutuhkan dalam menyelesaikan permasalahan kehidupan sehari-hari. Oleh karenanya pelajaran matematika harus sudah diberikan sejak dini kepada anak yaitu sejak anak duduk di bangku Sekolah Dasar.Jenning dan Dunne (Abdullah, 2008) mengatakan bahwa pada umumnya siswa mengalami kesulitan dalam mengaplikasikan matematika ke dalam situasi kehidupan real. Hal lain yang menyebabkan sulitnya matematika bagi siswa adalah karena pembelajaran matematika kurang bermakna. Guru dalam pembelajaran di kelas tidak mengaitkan denganskema yang telah dimiliki oleh siswa-siswa kurang diberikan kesempatan untuk menemukan kembali dan meng- konstruksikan sendiri ide-ide matematika, sehingga anak cepat lupa dan tidak dapat mengaplikasikan matematika.

Hasil pengamatan proses pembelajaran matematika pada siswa Kelas III SDN Pragaan Laok I pada semester II Tahun Pelajaran 2013/2014 didapatkan bahwa belum ada peningkatan keterampilan menghitung penjumlahan pecahan. Hal tersebut terlihat ketika guru menuliskan soal tentang pemjumlahan pecahan di papan tulis dan meminta siswa mengerjakannya di depan umum, tidak ada satupun siswa dari 20 siswa yang maju untuk mengerjakan soal tersebut ke depan. Berdasarkan uraian di atas, peneliti berusaha memberikan alternatif solusi dalam meningkatkan keterampilan siswa khususnya pada materi pecahan, yaitu dengan pembelajaran kooperatif tipe The Power Of two. 
Menurut Suprijono (2009:100-101), "model pembelajaran The Power Of Two merupakan model pembelajaran yang diawali dengan mengajukan pertanyaan yang membutuhkan pemikiran kritis, dilanjutkan dengan diskusi serta membandingkan informasi kepada kelompok lain". Diskusi dalam hal ini dilakukan setelah siswa mengadakan perenungan secara mandiri serta mencoba mengerjakan persoalan yang telah diberikan. Sedangkan menurut Ramadhan (2009), "The Power Of Two merupakan model pembelajaran yang menggabungkan kekuatan dua kepala dengan membentuk kelompok kecil”. Yang dimaksud kelompok kecil adalah siswa berpasangan sesuai ketentuan dari guru ataupun teman sebangku mereka. Mafatih (2007:89) menjelaskan bahwa "The Power Of Two adalah belajar dalam kelompok kecil dengan menumbuhkan kerja sama secara maksimal melalui kegiatan pembelajaran oleh teman sendiri dengan anggota dua orang di dalamnya untuk mencapai kompetensi dasar". Model pembelajaran The Power Of Two adalah kegiatan yang dilakukan untuk menngkatkan belajar kolaboratif dan mendorong munculnya keuntungan dari sinergi itu, sebab dua orang tentu lebih baik dari pada satu.

Tabel 1.Sintakmatik Model Pembelajaran The Power Of Two

\begin{tabular}{|c|c|}
\hline Fase-Fase & Perilaku Guru \\
\hline $\begin{array}{l}\text { Fase } 1 \\
\text { Memberikan Problem }\end{array}$ & Guru memberikan pertanyaan yang membutuhkan pemikiran \\
\hline $\begin{array}{l}\text { Fase } 2 \\
\text { Bekerja Mandiri }\end{array}$ & $\begin{array}{l}\text { Guru meminta siswa untuk memikirkan dan mengerjakan secara } \\
\text { mandiri }\end{array}$ \\
\hline $\begin{array}{l}\text { Fase } 3 \\
\text { Pembagian Kelompok }\end{array}$ & Guru membagi kelompok secara heterogen \\
\hline $\begin{array}{l}\text { Fase } 4 \\
\text { Diskusi Kelompok }\end{array}$ & $\begin{array}{l}\text { Guru meminta masing-masing kelompok untuk berdiskusi dan } \\
\text { membandingkan jawaban secara mandiri }\end{array}$ \\
\hline $\begin{array}{l}\text { Fase } 5 \\
\text { Diskusi Klasikal }\end{array}$ & $\begin{array}{l}\text { Guru dan semua kelompok berdiskusi serta membandingkan hasil } \\
\text { pekerjaan dari masing-masing Kelompok }\end{array}$ \\
\hline
\end{tabular}

Adapun kelebihan dari model pembelajaran The Power Of Two adalah membantu siswa untuk bisa bekerja sama dengan teman anggota kelompok, menghargai pendapat serta mengkonstruksi berbagai macam gagasan menjadi satu gagasan sebagai jawaban dari suatu permasalahan yang diberikan oleh guru. Sedangkan kelemahan dari model ini adalah siswa sulit menerima jawaban alternatif dari suatu permasalahan dan menganggap jawabannya yang paling benar. Jadi pembelajaran kooperatif tipe The Power Of Two adalah suatu model pembelajaran yang mengajarkan siswa untuk bisa berpikir secara mandiri, berkelompok dan berinteraksi sosial dengan siswa lain serta mengajarkan siswa untuk lebih menghargai pendapat teman yang bekerja dalam satu tim.

\section{Rumusan Masalah dan Tujuan Penelitian}

Melalui penelitian tindakan kelas ini akan diungkapkan rumusan masalah sebagai berikut;

1. Bagaimanakah peningkatan hasil belajar matematika materi pecahan pada siswa kelas III SDN Pragaan Laok I semester II tahun pelajaran 2013/2014 setelah melalui pembelajaran kooperatif tipe The Power Of Two?

2. Bagaimanakah proses pembelajaran matematika materi pecahan pada siswa kelas III SDN Pragaan Laok I semester II tahun pelajaran 2013/2014 setelah melalui pembelajaran kooperatif tipe The Power of Two ?

Sementara tujuan penelitian tindakan kelas ini untuk mendiskripsikan peningkatan hasil belajar matematika 
materi pecahan dan perubahan perilaku siswa kelas III SDN Pragaan Laok I Semester II tahun pelajaran 2013/2014.

\section{METODE PENELITIAN}

Penelitian ini merupakan penelitian tindakan kelas (classroom action research) jenis partisipan yaitu keterlibatan langsung peneliti dari proses awal hingga akhir baik dari proses perencanaan hingga pelaporan. Penelitian ini juga menggunakan pendekatan deskriptif kualitatif. Metode deskriptif berusaha mengungkapkan gejala secara menyeluruh sesuai dengan konteks melalui pengumpulan data berlatar alami (natural setting) dengan peneliti sebagai instrumen utama serta lebih menonjolkan proses dan makna dari sudut pandang subyek yang diteliti. Penelitian ini menggunakan prosedur kerja dan siklus spiral dari perencanaan, tindakan, observasi, dan refleksi.

Penelitian dilaksanakan di kelas III SDN Pragaan Laok I Kecamatan. Pragaan semester II pada tahun pelajaran 20132014. SDN Pragaan Laok I terletak di Dusun Aeng Soka Desa Pragaan Laok Kecamatan Pragaan Kabupaten Sumenep. Penelitian ini dilaksanakan mulai dari perencanaan sampai akhir penelitian hingga penulisan laporan penelitian.

Subjek penelitian adalah siswa kelas III SDN Pragaan Laok I Kecamatan Pragaan Kabupaten Sumenep pada tahun pelajaran 2013-2014 semester II. Siswa kelas III berjumlah 20 orang terdiri dari 12 laki-laki dan 8 perempuan.

Data yang dikumpulkan dalam penelitian ini antara lain; (1) hasil pekerjaan siswa pada kegiatan dan tes pada setiap akhir tindakan dilakukan, (2) hasil observasi siswa guna mengamati kegiatan di kelas selama pembelajaran yang berlangsung.

Adapun teknik pengumpulan data dilakukan dengan menggunakan instrumen lembar observasi, tes, dan dokumentasi. Proses penganalisaan data penelitian ini berpedoman pada langkah- langkah analisis data penelitian kualitatif. Langkah-langkah analisis tersebut terdiri dari tiga alur kegaiatan yang terjadi secara bersamaan yaitu; (reduksi data, (2) penyajian data, (3)penarikan kesimpulan. Tahap-tahap yang dilaksanakan dalam penelitian ini adalah; pra tindakan dan pelaksanaan kegiatan penelitian.

\section{HASIL DAN PEMBAHASAN Deskripsi Pra Siklus}

Dari data nilai harian siswa yang dimiliki peniliti sebelum diadakan penelitian adalah sebagai berikut;

Tabel 2. Data Nilai Ulangan Harian Siswa

\begin{tabular}{|c|c|c|c|c|}
\hline No & $\begin{array}{c}\text { Interval } \\
\text { Nilai } \\
\end{array}$ & Frek & $\%$ & Ket \\
\hline 1 & $51-55$ & 9 & 45 & Belum tuntas \\
\hline 2 & $56-60$ & 6 & 30 & Belum tuntas \\
\hline 3 & $61-65$ & 1 & 5 & Tuntas \\
\hline 4 & 66-70 & 2 & 10 & Tuntas \\
\hline 5 & $71-75$ & 2 & 10 & Tuntas \\
\hline 6 & $76-80$ & 0 & 0 & Tuntas \\
\hline 7 & $81-85$ & 0 & 0 & Tuntas \\
\hline 8 & $86-90$ & 0 & 0 & Tuntas \\
\hline 9 & $91-95$ & 0 & 0 & Tuntas \\
\hline 10 & 96-100 & 0 & 0 & Tuntas \\
\hline \multicolumn{2}{|c|}{ Jumlah } & 20 & 100 & \\
\hline
\end{tabular}

Dari data tersebut didapatkan bahwa hanya terdapat 5 siswa atau $25 \%$ yang memperoleh nilai di atas KKM dan terdapat 15 siswa atau $75 \%$ memperoleh nilai dibawah KKM. Sementara rata-rata nilai 58,60 .

\section{Deskripsi Siklus I}

Siklus I dilaksanakan dalam 2 kali pertemuan dengan masing-masing pertemuan berlangsung selama 2 x 35 menit. Subyek penelitian adalah kelas V SDN Pragaan Laok I Kecamatan PragaanSemester II Tahun Pelajaran 2013/2014 yang berjumlah 20 siswa. Kegiatan belajar mengajar dilakukan oleh peneliti sendiri dengan bantuan atau bimbingan dari guru mata pelajaran kelas.

Hasil pengamatan tentang proses pembelajaran atau aktivitas siswa dapat 
dilihat dalam tabel dibawah ini sebagai berikut :

Tabel 3. Prosentase Proses Pembelajaran Siklus I

\begin{tabular}{lcccc}
\hline \multicolumn{1}{c}{ Aspek } & $\begin{array}{c}\text { Jml } \\
\text { Skor }\end{array}$ & Rata2 & \% & Ket \\
\hline Keaktifan & 56 & 2,8 & 60 & Cukup \\
\hline Keberanian & 50 & 2,5 & 55 & Cukup \\
\hline Kerja sama & 65 & 3,25 & 70 & baik \\
\hline Ketelitian & 40 & 1,71 & 45 & Kurang \\
\hline
\end{tabular}

Berdasarkan tabel di atas perolehan skor proses pembelajaran siswa siklus I dari jumlah 20 siswa: aspek keaktifan memperoleh jumlah skor 56, rata-rata nilai 2,8 persentase $60 \%$ dengan kategori cukup aktif. Aspek Keberanian memperoleh jumlah skor 50, rata-rata nilai 2,5, persentase 55\% dengan kategori cukup berani. Aspek kerjasama memperoleh skor 65 , rata-rata nilai 3,25 persentase $70 \%$ kategori cukup baik. Aspek ketelitian memperoleh skor 61, rata-rata nilai 1,71 dan persentase $45 \%$ dengan kategori kurang.

Hasil belajar siswa berdasarkan nilai tes dan ketuntasan belajar pada siklus I dapat dilihat pada tabel 4.

Tabel 4. Nilai Tes dan Ketuntasan Belajar Siklus I

\begin{tabular}{ccccc}
\hline No & $\begin{array}{c}\text { Interval } \\
\text { Nilai }\end{array}$ & Frek & $\%$ & Keterangan \\
\hline 1 & $51-55$ & 5 & 25 & Belum tuntas \\
\hline 2 & $56-60$ & 4 & 20 & Belum tuntas \\
\hline 3 & $61-65$ & 4 & 20 & Tuntas \\
\hline
\end{tabular}

\begin{tabular}{ccccc}
\hline No & $\begin{array}{c}\text { Interval } \\
\text { Nilai }\end{array}$ & Frek & $\boldsymbol{\%}$ & Keterangan \\
\hline 4 & $66-70$ & 4 & 20 & Tuntas \\
\hline 5 & $71-75$ & 3 & 15 & Tuntas \\
\hline 6 & $76-80$ & 0 & 0 & Tuntas \\
\hline 7 & $81-85$ & 0 & 0 & Tuntas \\
\hline 8 & $86-90$ & 0 & 0 & Tuntas \\
\hline 9 & $91-95$ & 0 & 0 & Tuntas \\
\hline 10 & $96-100$ & 0 & 0 & Tuntas \\
\hline \multicolumn{2}{c}{ Jumlah } & $\mathbf{2 0}$ & $\mathbf{1 0 0}$ & \\
\hline
\end{tabular}

Berdasarkan tabel 4 tentang hasil nilai tes matematika siklus I kelas III SD Negeri Pragaan Laok I semester II tahun pelajaran 2013/2014 ada 9 siswa atau $45 \%$ dinyatakan belum tuntas atau nilai yang masih di bawah KKM 61, sedangkan yang telah tuntas ada 11 siswa atau 55\%, terdiri dari 5 siswa memperoleh nilai antara 51-55, 4 siswa memperoleh nilai antara 56-60, 4 siswa memperoleh nilai antara 61-65, 4 siswa memperoleh nilai antara 66-70 dan 3 siswa memperoleh nilai antara 71-75. Nilai rata-rata ulangan kondisi awal yaitu: 61,35 ;

Tabel 5. Nilai Rata-rata Tes Siklus I

\begin{tabular}{lc}
\hline \multicolumn{1}{c}{ Data } & Nilai \\
\hline Nilai Tertinggi & 75 \\
\hline Nilai Terendah & 51 \\
\hline Rata-rata & 61,35 \\
\hline
\end{tabular}

Ketuntasan siswa dari pra-siklus ke siklus I disajikan dengan grafik pada gambar 1 berikut.

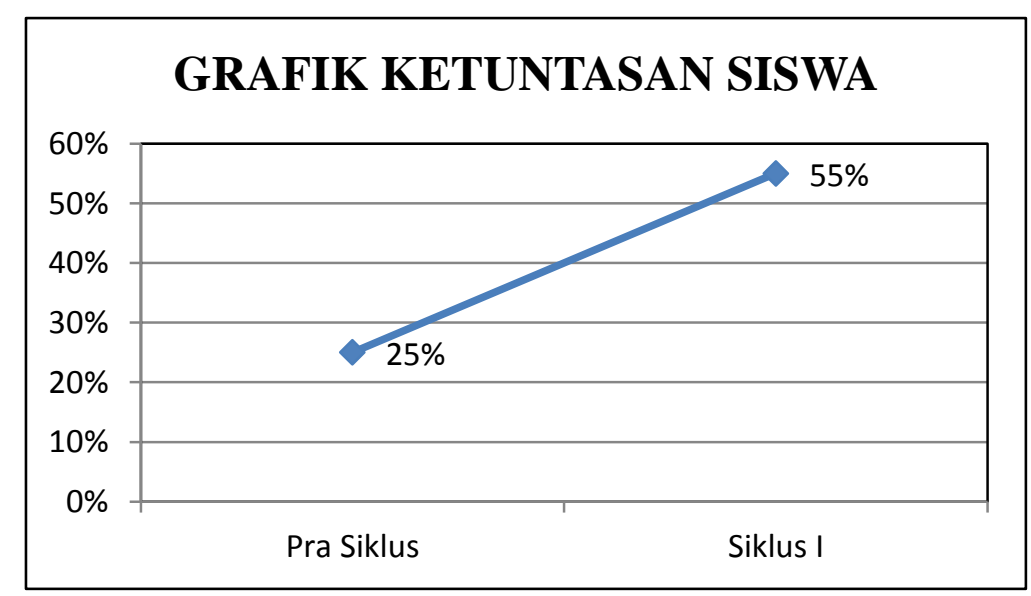

Gambar 1. Grafik Ketuntasan Siswa Pra Siklus ke Siklus I 


\section{Deskripsi Siklus II}

Hasil pengamatan tentang proses pembelajaran dapat dilihat dalam tabel 6 .

Tabel 6. Prosentase Proses Pembelajaran Siklus II

\begin{tabular}{|c|c|c|c|c|}
\hline Aspek & $\begin{array}{c}\text { Jumlah } \\
\text { Skor }\end{array}$ & $\begin{array}{l}\text { Rata- } \\
\text { rata }\end{array}$ & $\%$ & Keterangan \\
\hline Keaktifan & 73 & 3,65 & 91,25 & Baik Sekali \\
\hline Keberanian & 63 & 3,15 & 78,75 & Baik \\
\hline Kerja sama & 78 & 3,9 & 97,5 & Baik Sekali \\
\hline Ketelitian & 76 & 3,8 & 95 & Baik Sekali \\
\hline
\end{tabular}

Berdasarkan tabel 6, perolehan proses pembelajaran siswa siklus II dari jumlah 20 siswa: aspek keaktifan memperoleh jumlah skor 73, rata-rata nilai 3,65 persentase $91,25 \%$ kategori baik sekali. Aspek keberanian dengan jumlah skor 63, rata-rata nilai 3,15, persentase 78,75\%, kategori baik. Aspek kerjasama memperoleh skor 78, rata-rata nilai 3,9, persentase 91,96\% kategori baik sekali. Aspek ketelitian memperoleh skor 76 rata-rata nilai 3,80 persentase 95 $\%$ dengan kategori baik sekali.

Hasil belajar siswa pada siklus I dapat dilihat dalam tabel dibawah ini

Tabel 7. Nilai Tes dan Ketuntasan Belajar Siklus II

\begin{tabular}{ccccl}
\hline No & $\begin{array}{c}\text { Interval } \\
\text { Nilai }\end{array}$ & Frek & $\%$ & Keterangan \\
\hline 1 & $61-70$ & 3 & 15 & Tuntas \\
\hline 2 & $71-75$ & 7 & 35 & Tuntas \\
\hline 3 & $76-80$ & 4 & 20 & Tuntas \\
\hline
\end{tabular}

\begin{tabular}{ccccl}
\hline No & $\begin{array}{c}\text { Interval } \\
\text { Nilai }\end{array}$ & Frek & $\%$ & Keterangan \\
\hline 4 & $81-85$ & 3 & 15 & Tuntas \\
\hline 5 & $86-90$ & 2 & 10 & Tuntas \\
\hline 6 & $91-95$ & 1 & 5 & Tuntas \\
\hline 7 & $96-100$ & 0 & 0 & Tuntas \\
\hline Jumlah & 20 & 100 & \\
\hline
\end{tabular}

Berdasarkan dari tabel di atas tentang hasil nilai tes matematika siklus II kelas III SD Negeri Pragaan Laok semester II tahun pelajaran 2013/2014 seluruh siswa 20 siswa atau $100 \%$ telah mencapai nilai di atas KKM 61. Nilai terdiri dari 3 siswa memperoleh nilai antara 66-70, 7 siswa memperoleh nilai antara 71-75, 4 siswa memperoleh nilai antara 76-80, 3 siswa memperoleh nilai antara 81-85, 2 siswa memperoleh nilai antara 86-90, 1 siswa memperoleh nilai antara 91-95, dan 0 siswa memperoleh nilai antara 96-100. nilai rata-rata ulangan siklus II yaitu: 82,36 (sebagaimana tersaji dalam tabel 8).

Tabel 8. Nilai Rata-rata Tes Siklus II

\begin{tabular}{lc}
\multicolumn{1}{c}{ Data } & Nilai \\
\hline Nilai Tertinggi & 93 \\
\hline Nilai Terendah & 66 \\
\hline Rata-rata & 82,36 \\
\hline
\end{tabular}

Ketuntasan siswa dari pra-siklus ke siklus I ke siklus II disajikan dengan grafik pada gambar 2 berikut.

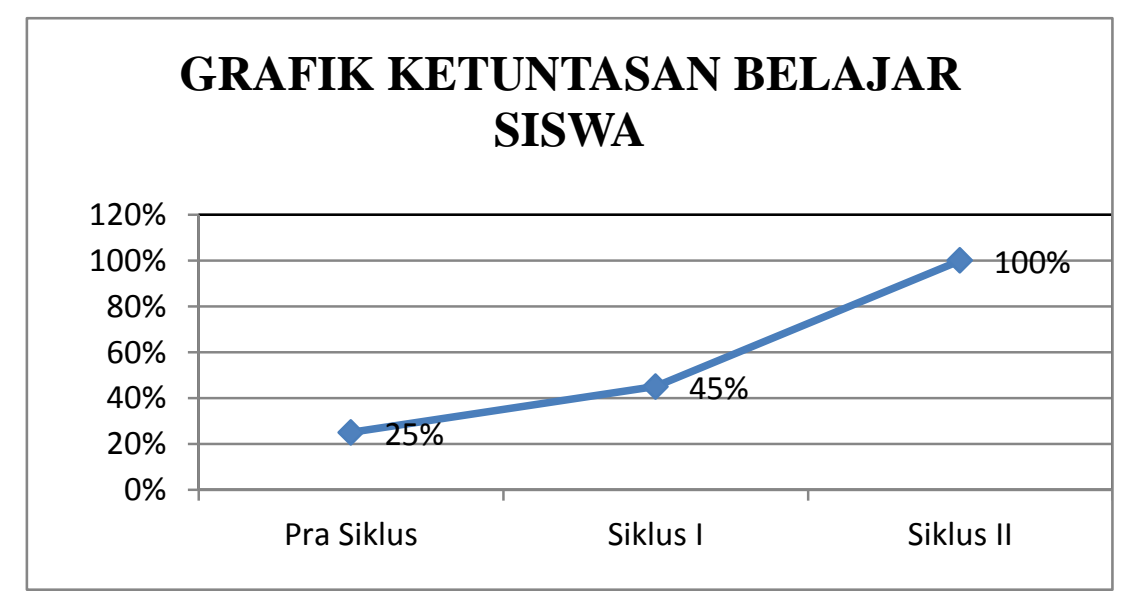

Gambar 2. Grafik Ketuntasan Belajar Siswa dari Pra-siklus, Siklus I, dan Siklus II 


\section{PEMBAHASAN}

Proses pembelajaran pada siklus I berjalan dengan baik meskipun pada tahap awal kegiatan inti siswa masih belum terbiasa belajar kelompok dengan menerapkan model pembelajaran kooperatif The Power Of Two sehingga mereka sulit untuk memahami langkahlangkah pembelajaran kooperatif tipe The Power Of Two. Hal tersebut, menyebabkab aktivitas belajar siswa pada materi pecahan masih belum tampak, karena siswa masih belum bisa menyelesaikan soal secara sistematis, siswa masih membutuhkan bantuan dari teman maupun guru untuk menyelesaikan soal-soal.

Kerjasama dalam kelompok pun belum terbangun dengan baik, hal tersebut terlihat saat mereka membuat kesepakatan untuk jawaban baru. Kesepakatan yang terbentuk masih merupakan ide dari salah satu siswa. Hai ini tentunya tidak sesuai dengan teori yang disampaikan oleh Supijono (2009:100), bahwa model pembelajaran kooperatif tipe The Power Of Two mengarahkan siswa untuk saling bekerjasama dalam kelompok yang mendorong peserta didik untuk berpikir kritis. Berdasarkan teori tersebut seharusnya siswa dapat bekerjasama untuk membuat kesepakatan baru, diamana pemikiran yang muncul tidak hanya dari satu orang tapi tetapi dari dua orang.

Dari hasil tersebut ternyata ada perbedaan antara teori dengan temuan di lapangan. Pada temuan siklus I, kesepakatan yang terbentuk ternyata masih ide satu orang padahal menurut teori, kesepakan yang terbentuk seharusnya berasal dari pemikiran dua orang. Temuan yang berbeda pada siklus I tersebut dapat dijadikan masukan untuk perbaikan pada siklus II sehingga, penerapan model The Power Of Two berjalan secara maksimal dan prosedural.
Adanya peningkatan Proses pembelajaran siswa dari siklus I ke siklus II menunjukkan bahwa model pembelajaran kooperatif tipe The Power Of Two dalam pembelajaran matematika materi Pecahan di kelas III SDN Pragaan Laok I Kecamatan Pragaan berhasil diterapkan dan untuk selanjutnya dapat diterapkan pada materi lain yang cocok dengan karakter model pembelajaran kooperatif The Power Of Two. Hal isi sesuai dengan teori yang disampaikan oleh Anggoro (2000:2.4) bahwa keberhasilan siswa dalam ranah afektif dapat dilihat dari besarnya minat dalam mengikuti pembelajaran atau dari keterlibatannya dalam diskusi kelas. Melalui diskusi yang melibatkan pemikiran dua orang tersebut. Diharpakan akan menghasilkan sesuatu yang jauh lebih baik jika dibandingkan dengan pemikiran satu orang saja.

Berdasarkan paparan di atas terlihat bahwa aktivitas guru ternyata berpengaruh terhdap proses pembelaran siswa. Jika aktivitas guru mengalami peningkatan maka, aktivitas siswapun juga mengalami peningkatan. Peningkatan aktivitas siswa ini dapat terlihat utamanya pada siklus II. Pada siklus II ini, siswa sudah mampu menyatukan ide dalam membuat kesepakatan untuk jawaban baru. Kesepakatan yang muncul tidak lagi ini tentunya telah sesuai dengan prinsip The Power Of Two bahwa berpikir berdua jauh lebih baik dari berpikir sendiri.

Hasil belajar siswa dilihat dari nilai akhir pembelajaran di setiap pertemuan. Dengan melihat analisis hasil tes dari 20 siswa kelas III SDN Pragaan Laok I Kecamatan Pragaaan yang dijadikan objek penelitian maka dapat dikatakan dalam setiap Tindakan ada peningkatan hasil belajar siswa pada materi pecahan. Hal ini ditunjukkan dengan peningkatan nilai rata-rata hasil belajar siswa pada pelaksanaan siklus I sampai pada siklus II. 


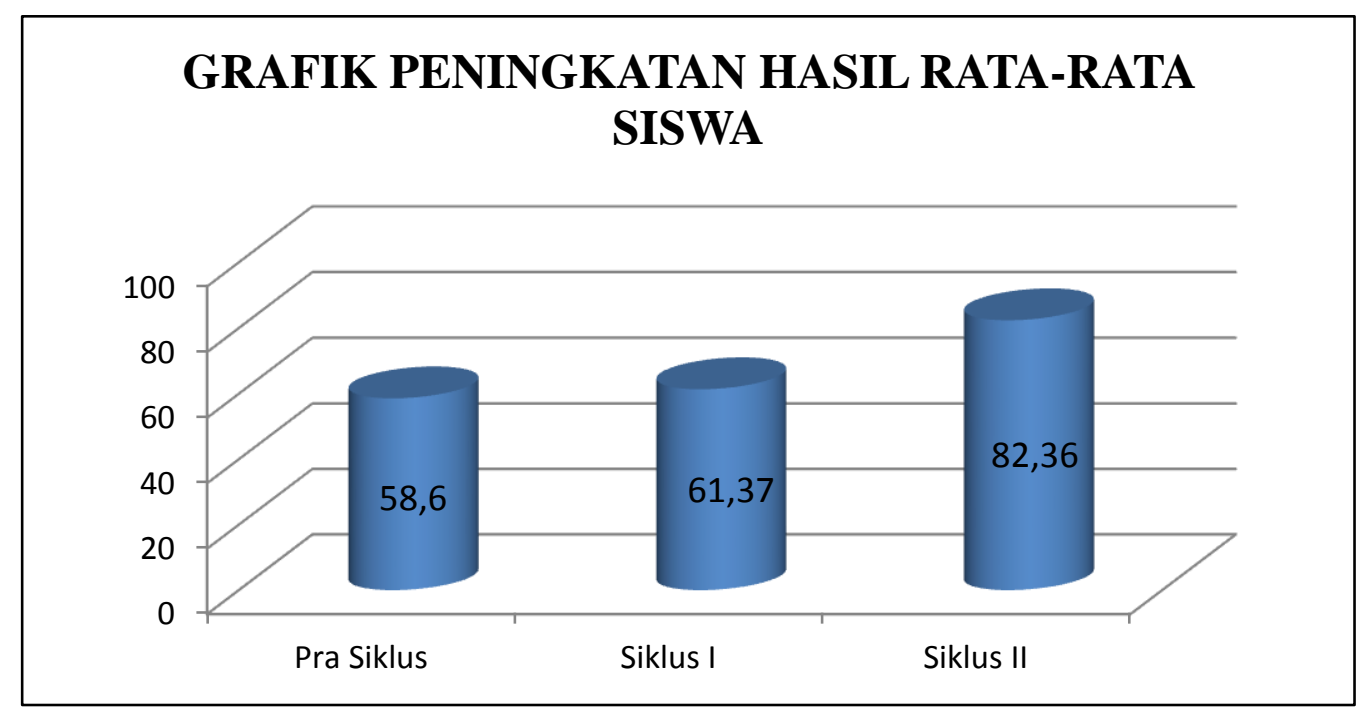

Gambar 3. Grafik Peningkatan Hasil Rata-rata Siswa

Adanya peningkatan nilai rata-rata hasil belajar membuktikan bahwa siswa semakin terampil dalam menyelesaikan soal-soal yang terkait dengan materi pecahan. Peningkatan tersebut menunjukkan bahwa terjadi perubahan hasil belajar dari siklus I ke Siklus II. Hal ini sesuai dengan yang dikemukan Hamalik (2009:36) bahwa hasil belajar bukan suatu penguasaan hasil latihan namun, merupakan perubahan kelakuan. Perubahan perilaku tersebut terlihat dari peningkatan kemampuan siswa dalam belajar dengan menerapkan langkahlangkah model pembelajaran kooperatif tipe The Power Of Two. Jadi hasil belajar tidak hanya perubahan skor atau nilai akan tetapi juga perubahan kemampuan setelah mengikuti proses belajar.

Berdasar hal tersebut, maka pembelajaran melalui model kooperatif The Power Of Two dinyatakan telah berhasil meningkatkan hasil belajar siswa pada materi pecahan di kelas III SDN Pragaan laok I Kecamatan Pragaan Kabupaten Sumenep. Untuk itu, kedepannya model ini dapat digunakan untuk pembalajaran lain yang materinya sesuai dengan karakter model The Power Of Two. Namun, harus diingat bahwa dalam meningkatkan hasil belajar siswa dengan menggunakan model ini dibutuhkan kesiapan dan kematangan dari guru untuk dapat mengatasi kesulitankesulitan yang muncul saat pembelajaran berlangsung.

\section{KESIMPULAN DAN SARAN Kesimpulan}

Berdasarkan paparan data dan pembahasan, dapat disimpulkan sebagai berikut.

1. Penerapan model pembelajaran kooperatif tipe The Power Of Two Materi pecahan pada siswa kelas III SDN Pragaan Laok I Kecamatan Pragaan Kabupaten Sumenep sangat baik. Hal ini dapat dibuktikan bahwa proses pembelajaran siswa mengalami peningkatan dari siklus I ke siklus II. Peningkatan ini ternyata dipengaruhi oleh peningkatan aktivitas guru. Hal ini dibuktikan dari kenaikan nilai rata-rata aktivitas siswa dari siklus I ke siklus II.

2. Penerapan model pembelajaran kooperatif tipe The Power Of Two materi pecahan pada siswa kelas III SDN Pragaan Laok I Kecamatan Pragaan dapat meningkatkan hasil belajar siswa. Hal ini dapat dibuktikan dari kenaikan nilai ratarata siswa dari siklus I ke siklus II. 


\section{Saran}

Berdasarkan hasil penelitian dan kajian tentang implementasi model pembelajaran kooperatif The Power Of Two pada penelitian tindakan kelas ini dapat disarankan bahwa :

1. Peneliti hendaknya lebih peka terhadap permasalahn pembelajaran yang terjadi di sekolah sehingga mampu menggunakan berbagai model pembelajaran yang sesuai untuk mengatasiya.

2. Siswa hendaknya selalu bekerja sama dalam menyelesaikan permasalahan apapun.

3. Guru hendaknya lebih mampu memotivasi siswa untuk lebih mengembangkan keterampilan kooperetaif atau kerja sama dalam kegiatan kelompok.

4. Sekolah hendaknya senantiasa mengembangkan kualitasnya melalui peningkatan pembelajaran yang berlangsung di sekolah tersebut.

5. Bagi peneliti lain penerapan model pembelajaran kooperatif The Power Of Two dapat dilakukan pada mata pelajaran matematika materi lain seauh materi tersebut sesuai dengan karakter model pembelajaran kooperatif The Power Of Two.

\section{DAFTAR PUSTAKA}

Anngoro, Toha. 2008. Metode Penelitian. Jakarta: Universitas Terbuka.

Arikunto, Suharsimi. 2003. Dasar-dasar Evaluasi Pendidikan. Jakarta : Rineka Cipta.

Arikunto, Suharsimi. 2006. Prosedur Penelitian.J akarta: Rineka Cipta.

Ainurrahman. 2009. Belajar dan Pembelajaran. Bandung: Alfabeta Bumi Aksara.

Departemen Pendidikan Nasional. 2006.

Peraturan Menteri Pendidikan

Nasional Republik Indonesia

Nomor 22 Tahun 2006 tentang

Standar isi untuk Satuan

Pendidikan Dasar dan Menengah.
Lampiran: Standar Keterampilan dan Keterampilan Dasar Mata Pelajaran Matematika untuk Sekolah Dasar (SD)/ Madrasah Ibtidaiyah (MI). Jakarta: Departemen Pendidikan Nasional.

Hamalik, Oemar. 2009. Kurikulum dan Pembelajaran. Jakarta : Bumi Aksara.

Mafatih, Ahmad Bisyri Hadi. 2007. Makalah Strategi Belajar Dengan Cara Kooperatif (Bidang Studi IPS). http://media.diknas.go. id. Diakses pada tanggal 28 Mei 2008 .

Slameto. 2003. Belajar Dan FaktorFaktor Yang Mempengaruhi. Jakarta: Rineka Cipta.

Suprijono, Agus. 2009. Cooperatif Learning. Yogyakarta: Pustaka Belajar.

Wiriatmadja, Rochiati. 2005. Metode Penelitian Tindakan Kelas. Bandung: PT Remaja Rosdakarya.

Zaini, Hisyam. 2008. Strategi Pembelajaran Aktif. Yogyakarta : Insan Madani. 